\title{
Preliminary Investigation of Pozzolanic Properties of Calcined Waste Kaolin
}

\author{
Yang HUANG ${ }^{1,2 *}$, Jie DENG ${ }^{3}$, Weiqing WANG ${ }^{1,2}$, Qiming FENG ${ }^{1,2}$, Zhonghui XU ${ }^{1,2}$ \\ ${ }^{1}$ Laboratory of Solid Waste Treatment and Resource Recycle, Ministry of Education, Mianyang 621010, China \\ ${ }^{2}$ Non-metallic Mineral Powder Modification and High Quality Utilization Technology of Sichuan Province Engineering \\ Laboratory, Mianyang 621010, China \\ ${ }^{3}$ Institute of Multipurpose Utilization of Mineral Resources, CAGS, Chengdu 610000, China \\ crossref http://dx.doi.org/10.5755/j01.ms.24.2.18192
}

Received 17 May 2017; accepted 20 September 2017

\begin{abstract}
Current research aims to investigate the influence of calcination temperature on the pozzolanic activity of the waste kaolin and the impact of calcination products on Portland cement hydration. The raw material with approximately $85 \%$ kaolinite was calcined to temperatures ranging between 500 and $1000^{\circ} \mathrm{C}$. The clay and its calcined products were characterized by TGA-DTA, SEM-EDS, XRD, FT-IR and BET. The pozzolanic activity of the calcined products was assessed by electrical conductivity test and compressive strength in mortars with $30 \%$ substitution of Portland cement. The effect of calcined products on Portland cement hydration was characterized by XRD and SEM. The results showed that the calcination temperature had an important influence on mineral phase transition and the pozzolanic activity of calcined products. The degree of disorder and pozzolanic activity of calcined products at $800{ }^{\circ} \mathrm{C}$ was the highest at temperatures ranging from 500 and $1000{ }^{\circ} \mathrm{C}$. The impact of calcined products on the hydration of blended systems was a combination of a filler effect at early ages and the pozzolanic reaction at later. The experimental results indicated that calcined products of waste kaolin constituted a potential source of high reactivity pozzolanic materials.

Keywords: calcined kaolin, pozzolanic activity, phase transition, Portland cement hydration.
\end{abstract}

\section{INTRODUCTION}

The annual global cement production has reached 4 billion tons according to data from the European Cement Association. However, the cement industry has faced many challenges in recent years. On the one hand, cement production releases massive $\mathrm{CO}_{2}$ gases and generate $\mathrm{SO}_{3}$ and $\mathrm{NO}_{\mathrm{x}}$ gases, which caused the greenhouse effect and incurred serious environmental impacts $[1,2]$. On the other hand, large amounts of energy and virgin materials were consumed in the cement production [3]. To reduce environmental damage and exploitation of natural resources, cement industry is actively looking for solutions [4]. One way to reach this objective is the use of industrial waste and by-products, such as fly ash, blast furnace slag, steel slag and silica fume, as clinker in the final composition of the cement. However, the reserves and forecast production of these materials do not meet the growth in demand for cement, the characteristics of these material are controlled by their production process rather than cement industry and their availability is closely related the economy development level [5].

It is in this context that calcined clay is becoming more prevalent as an alternative to cement clinker in the industry, because of their wide geographic distribution and excellent pozzolanic activity once calcined under suitable conditions. Calcination of clay minerals at temperatures ranging between $550{ }^{\circ} \mathrm{C}$ and $950{ }^{\circ} \mathrm{C}$ produces an amorphous silica compound, which is a very reactive aluminosilicate pozzolan [5]. The production of calcined clay reduces the amount of energy used and $\mathrm{CO}_{2}$ emissions, which because calcination temperatures are lower than that of clinker and decomposition of clays emits water vapor rather than $\mathrm{CO}_{2}$. The studies on calcination of different pure clays including kaolinite, illite and montmorillonite have shown that kaolinite has the highest pozzolanic activity and a lower activation temperature. However, pure kaolinite was relatively few in number and had a relative high price in comparison with other cementitious materials. The kaolin deposits generally contain a mixture of different clay minerals such as kaolinite, illite, and montmorillonite and relative large quantities of impurities such as quartz, feldspars, mica, rutile, hematite, sulfides, cristobalite and calcite $[6,7]$. The purification processing of natural kaolin is technically complicated and a costly barrier [7], which could require large processing facilities, consumes a lot of water and energy [7]. As a result, the potential to use natural kaolin as pozzolanic materials is of great interest.

Natural kaolin is widely widespread in pyrite-bearing strata, southwest of China. In the process of pyrite processing, a large number of kaolin were separated from the pyrite by floatation and disposed in tailings ponds, landfills or quarries. At present, these kaolins have not as yet been exploited, which not only waste natural resources but also occupy a lot of land and cause adverse effects to the local ecological environment. In this work, the waste kaolin clay from a tailing pond in the locality, having a significant content of impurities, such as rutile and calcite, was calcined to prepare pozzolanic material. The influence of calcination temperature on the pozzolanic activity of waste kaolin and the impact of the calcined products on Portland cement hydration were assessed in this paper. The findings would

\footnotetext{
* Corresponding author. Tel.: +86-816- 2419223; fax: +86-816-6089453.

E-mail address: swusthy@163.com (Y. Huang)
} 
aid in the utilization of available waste kaolin as potential pozzolanic material.

\section{EXPERIMENTAL}

\subsection{Raw materials}

The waste kaolin was obtained from a tailing ponds at Xuyong, a typical kaolin deposit located at the province of Sichuan, China. The clay from the tailing pond was gray in color and was not exploited at local. The chemical composition of the sample from XRF analysis is summarized in Table 1. The results showed that the main chemical compositions of raw materials were $\mathrm{SiO}_{2}$ and $\mathrm{Al}_{2} \mathrm{O}_{3}$, accounted for $69.17 \%$. The used waste kaolin was obtained after flotation of pyrite, and this means that it might contain some residue of pyrite, which was a critical point of its application in cement. However, the results displayed that the content of $\mathrm{SO}_{3}$ was only $1.74 \%$, which was less than the allowable maximum prescribed values $3.5 \%$ in the national standard GB/T 2847-2005. According to XRD analysis, the major mineral constituents were kaolinite $\left[\mathrm{Al}_{2} \mathrm{Si}_{2} \mathrm{O}_{5}(\mathrm{OH})_{4}\right]$ accompanied with small amount of calcite $\left[\mathrm{CaCO}_{3}\right]$ and anatase $\left[\mathrm{TiO}_{2}\right]$. Based on characteristic XRD peaks of each mineral in combination with the chemical analysis the estimated content of kaolinite, calcite and anatase was about 85, 8 and $5 \mathrm{wt} \%$, respectively. Therefore, the sample could be considered as high-grade kaolinite mineral resource. The median of the particles in the sample was determined to be $37.92 \mu \mathrm{m}$ using a laser diffraction particle size analyser, Beckman Coulter, LS 13 320, this was benefit to reduce crushing and grinding cost. The specific surface area (BET) of raw materials was determined to be $24.95 \mathrm{~m}^{2} / \mathrm{g}$ using Quantachrom Autosorb 1MP sorption analyzer.

Table 1. Chemical and mineralogical composition of materials

\begin{tabular}{|c|c|c|c|}
\hline Oxides & Content, mass \% & Phase & Content, mass \% \\
\hline $\mathrm{SiO}_{2}$ & 35.53 & kaolinite & 85 \\
\hline $\mathrm{Al}_{2} \mathrm{O}_{3}$ & 33.64 & calcite & 8 \\
\hline $\mathrm{Fe}_{2} \mathrm{O}_{3}$ & 3.12 & anatase & 5 \\
\hline $\mathrm{CaO}$ & 4.81 & other & 2 \\
\hline $\mathrm{MgO}$ & 0.21 & & \\
\hline $\mathrm{Na}_{2} \mathrm{O}$ & 0.21 & & \\
\hline $\mathrm{K}_{2} \mathrm{O}$ & 0.19 & & \\
\hline $\mathrm{TiO}_{2}$ & 4.63 & & \\
\hline $\mathrm{SO}_{3}$ & 1.74 & & \\
\hline $\mathrm{LOI}^{2}$ & 14.57 & & \\
\hline
\end{tabular}

\subsection{Calcination and grind of waste kaoin}

After being dried at $105^{\circ} \mathrm{C}$ for $24 \mathrm{~h}$ under air recirculation, waste kaolin was introduced in a programmable laboratory furnace once the desired calcination temperature was reached. After calcination, the calcined products were quickly cooled down to room temperature. Calcination of kaolinitic clay at temperatures ranging between $450{ }^{\circ} \mathrm{C}$ and $700^{\circ} \mathrm{C}$ produces metakaolinite. The calcination time was fixed to 120 min for all calcination temperatures. Calcined products were ground for about 30 min by GSDM-S3 ultrafine stirred mill to obtain better performance of pozzolanic materials. After grinding, particle size distribution of all the calcined products at different temperatures was very close: the $D_{10}(10 \% \mathrm{v} / \mathrm{v}$ particles are smaller than this size), $D_{50}$ (median particle diameter), and $D_{90}$ approximately were $1 \mu \mathrm{m}, 8 \mu \mathrm{m}$, and $26 \mu \mathrm{m}$, respectively (measured by a laser diffraction particle size analyser, Beckman Coulter, LS 13 320). This allowed that all samples could be used to compare the pozzolanic activity.

\subsection{Experimental methods for characterization of waste kaolin and their calcination products}

Thermal behavior of waste kaolin including TG-DTA was examined using an analyzer (Netzsch STA 449C). The samples were heated at a constant rate of $10^{\circ} \mathrm{C} / \mathrm{min}$ from ambient temperature to $1000^{\circ} \mathrm{C}$ in air atmosphere. The morphology of the waste kaolin was observed using scanning electron microscopy (Zeiss UItra55) and energy dispersive X-ray spectroscopy (Zeiss IE450X-Max80). The XRD data were collected on a Panalytical X'pert Pro diffractometer using $\mathrm{Cu}-\mathrm{K} \alpha$ graphite-monochromatized radiation $\left(\lambda=1.5418 \AA\right.$ ) in the $2 \theta$ range $3-80^{\circ}$ (step size: $0.02^{\circ} 2 \theta$, time per step: $0.8 \mathrm{~s}$ ). The working conditions were $40 \mathrm{kV}$ and $30 \mathrm{~mA}$. FTIR measurements were performed on a Perkin Elmer Spectrum 400 on the solid sample prepared using $\mathrm{KBr}$ pressed disk technique over the wave number range of $4000-400 \mathrm{~cm}^{-1}$. Surface area analyses were measured by the Brunauer-Emmett-Teller (BET) gas sorption method using the Quantachrom Autosorb 1MP sorption analyzer.

\subsection{Assessment of pozzolanic activity}

The pozzolanic activity of calcined products was measured by electrical conductivity test and strength activity index (SAI) calculated as the ratio of the compressive strength of blended cement to the strength of the Portland cement (PC) at 3, 7 and 28 days of hydration. Electrical conductivity test was determined using a similar procedure to those proposed by Luxan et al [8]. and modified by $\mathrm{Yu}$ et al [9]. $0.3000 \mathrm{~g} \mathrm{Ca}(\mathrm{OH})_{2}$ were added to a glass beaker containing $200 \mathrm{~mL}$ deionized water at $40 \pm 1{ }^{\circ} \mathrm{C}$. The original electrical conductivity $\left(E_{1}\right)$ of $\mathrm{Ca}(\mathrm{OH})_{2}$ solution was measured using a Jeway 4010 conductivity meter. And then $5 \mathrm{~g}$ of calcined products was added with the solution under continuous stirring. After 2 minutes, the second electrical conductivity $\left(E_{2}\right)$ of $\mathrm{Ca}(\mathrm{OH})_{2}$ solution was recorded. Difference value of electrical conductivity between $E_{1}$ and $E_{2}$ was used to display the pozzolanic activity of calcined products.

Compressive strength was assessed on mortar cubes $(40 \times 40 \times 160 \mathrm{~mm})$ made with standard sand (1:3) and a water/cementing material ratio of 0.50 . Control mortar cubes were prepared using PC. The blended cement was composed by $30 \% \mathrm{w} / \mathrm{w}$ of calcined products and $70 \% \mathrm{w} / \mathrm{w}$ of Portland cement. The mortar was mixed in a planetary orbital mixer for $5 \mathrm{~min}$ and the specimens molded and compacted according to Chinese National Standard GB/T17671 - 1999. The mortars were first cured in a fog room at $20^{\circ} \mathrm{C}$ and $95 \%$ relative humidity for $24 \mathrm{~h}$, and then they were stripped from their molds and placed in water at $20{ }^{\circ} \mathrm{C}$ until testing ages. At the age of 3,7 and 28 days, the compressive strengths were measured the average of three specimens using universal testing machine ETM-305F-Z. 
Finally, the strength activity index (SAI) was calculated as the ratio of the compressive strength of blended cement mortar (A) to the strength of the PC mortar (B) at the same age, as percentage.

\subsection{Analysis of hydration product}

The hydration products of samples were prepared on pastes cubes $(20 \times 20 \times 20 \mathrm{~mm})$ made with a water/cementing material ratio of 0.5 . The cementing material consisted in a blend of $20-30 \%$ by mass of calcined products under the optimum conditions pastes and $80-70 \%$ of PC. A pastes containing $100 \%$ of PC was also studied. When the specified curing ages were reached, the hydration reaction of the cement paste was stopped by crushing the paste specimens into pieces of about $3-5 \mathrm{~mm}$ size, and then immersing them in ethanol for $24 \mathrm{~h}$. After that the paste sample was dried in vacuum desiccators at $40{ }^{\circ} \mathrm{C}$ for $24 \mathrm{~h}$. The specimens were then grinded into fine powder to be used in XRD and SEM measurements. The measurement conditions of the XRD and SEM was same as above work.

\section{RESULTS AND DISCUSSION}

\subsection{Characterization of waste kaolin}

TG-DTA was used to analyze thermal behavior of waste kaolin and was shown in Fig. 1. In the TG curve, the mass loss was $1.51 \%$ at below $120{ }^{\circ} \mathrm{C}$, corresponded with the removal of water adsorbed from waste kaolin surface. While, in the DTA curve, endothermic peak was weak during this desorption process. The second significant the mass loss in the TG curve was $11.21 \%$ in the temperature range $450-630^{\circ} \mathrm{C}$, which was associated with de-hydroxylation of kaolinite and formation of metakaolin. The center of the endothermic peak was located at ca. $510^{\circ} \mathrm{C}$ in the DTA curve. The third event in the TG curve was located in the temperature range $680-730^{\circ} \mathrm{C}$, the mass loss was 1.26 wt. $\%$ due to decomposition of calcite. The center was located at approximately $704{ }^{\circ} \mathrm{C}$ in the DTA curve. The last effect was recorded in the DTA curve was exothermic peaks at $990^{\circ} \mathrm{C}$, which was related to recrystallization and mullite formation according to the following reaction: $\left(2 \mathrm{Al}_{2} \mathrm{O}_{3} \cdot 3 \mathrm{SiO}_{2}\right) \rightarrow 2\left(3 \mathrm{Al}_{2} \mathrm{O}_{3} \cdot 2 \mathrm{SiO}_{2}\right)+5 \mathrm{SiO}_{2}$. The mullite formation reduced reactivity and pozzolanic characteristic of the calcined products [10].

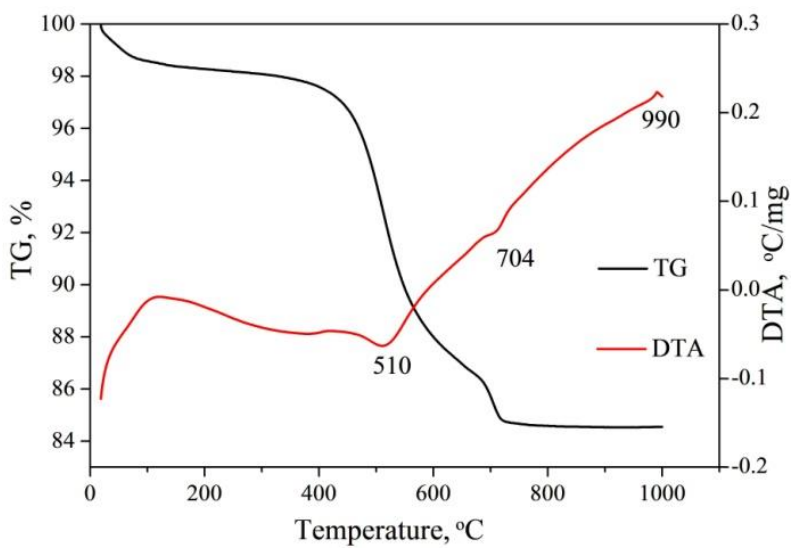

Fig. 1. DTA-TG curves of waste kaolin
The SEM-EDS micrographs of waste kaolin were presented in Fig. 2. Typical plate-like particles arising from lamellar structure of kaolinite crystals were dominant in the raw materials. SEM images of the sample presented an incomplete or irregular of crystal edge and an inhomogenous particle size distribution. It was difficult to find the impurity minerals in the SEM images (Fig. 2 a and b), such as calcite and anatase, because of their low content. In general, the influence of iron and titanium on the whiteness and quality of kaolin was significantly. In order to clarify the micro-distribution of $\mathrm{Fe}$ and $\mathrm{Ti}$, the element mapping for Fe and $\mathrm{Ti}$ was detected by SEM-EDS analysis (Fig. $2 \mathrm{c}$ and d). The results showed that Fe and Ti were uniformly distributed in the raw kaolin and their quality percentage was $0.86 \%$ and $0.91 \%$ respectively. The existence of $\mathrm{Fe}$ and $\mathrm{Ti}$ impurities would greatly affect the quality of raw kaolin [11] and decreased its commercial value [12]. In addition, the fineness of these impurity minerals was so small and highly dispersed distribution that they were not separated from kaolin by common methods, such as flotation and bleach. Therefore, calcined the waste kaolin as pozzolanic admixture in Portland cement was suitable, because it not only could be consumed the waste kaolin on large scale but also could not consider the impact of impurities.

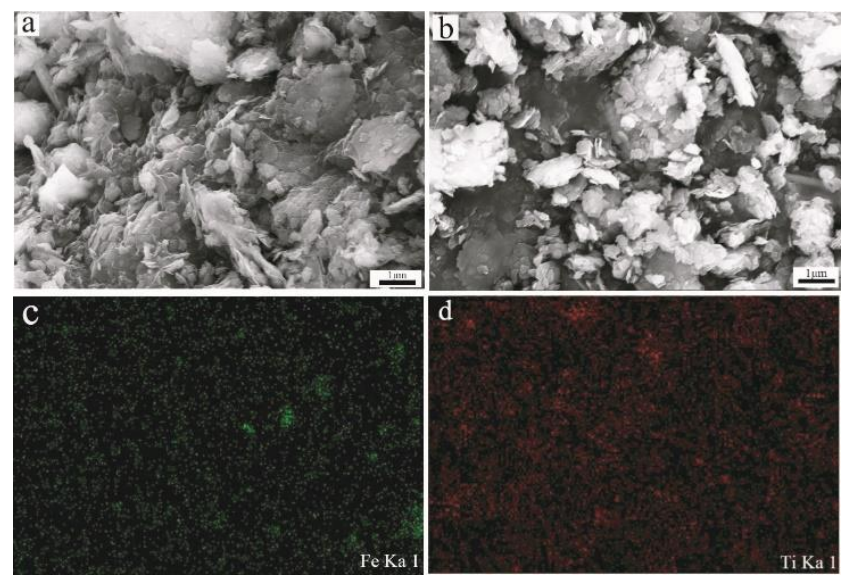

Fig. 2. a, b-the SEM images of the waste kaolin; $c$-element mapping for $\mathrm{Fe}$; $\mathrm{d}$-element mapping for $\mathrm{Ti}$

\subsection{Characterization of the calcined products at different temperatures}

Fig. 3 presents the XRD patterns of waste kaolin after calcination in the $500-1000{ }^{\circ} \mathrm{C}$ range, as well as the XRD patterns of the untreated kaolin. As it was observed at $500{ }^{\circ} \mathrm{C}$, obvious diffraction peaks still appeared at $2 \theta=12.41^{\circ}$, corresponded to the planes (001) of kaolinite, indicating that crystal structure of kaolinite had not been completely destroyed. However, the characteristic reflections of kaolinite were reduced, which suggested that a significant decrease in the crystallinity as well as kaolin to amorphous transformation had occurred. At $600{ }^{\circ} \mathrm{C}$, practically all peaks corresponding to kaolinite had disappeared, illuminating a very significant loss of crystallinity. The XRD patterns at $700{ }^{\circ} \mathrm{C}$ shown that the characteristic reflections of calcite were removed at $2 \theta=23.19^{\circ}, 29.48^{\circ}, 36.04^{\circ}$, and $39.28^{\circ}$. This was in good agreement with the TG-DTA analysis which confirmed 
endothermic decomposition of calcite at ca. $700{ }^{\circ} \mathrm{C}$. At $800{ }^{\circ} \mathrm{C}$, the characteristic diffraction peaks at $2 \theta=25.26^{\circ}$, $47.91^{\circ}, 53.94^{\circ}$, and $62.59^{\circ}$ corresponded with anatase that was the significant crystalline mineral in calcined products. Calcined products shown very clear weak diffraction peaks at $2 \theta=27.39$ resulted from rutile at $800{ }^{\circ} \mathrm{C}$ indicating the transformation of the anatase crystal structure. The mullite were observed from the XRD patterns of calcined products at $900{ }^{\circ} \mathrm{C}$ and $1000{ }^{\circ} \mathrm{C}$, which implied the recrystallization of the metakaolinite [13]. Compared with all XRD patterns, the degree of disorder of the calcined products was highest at $800{ }^{\circ} \mathrm{C}$ which might have high pozzolanic activity.

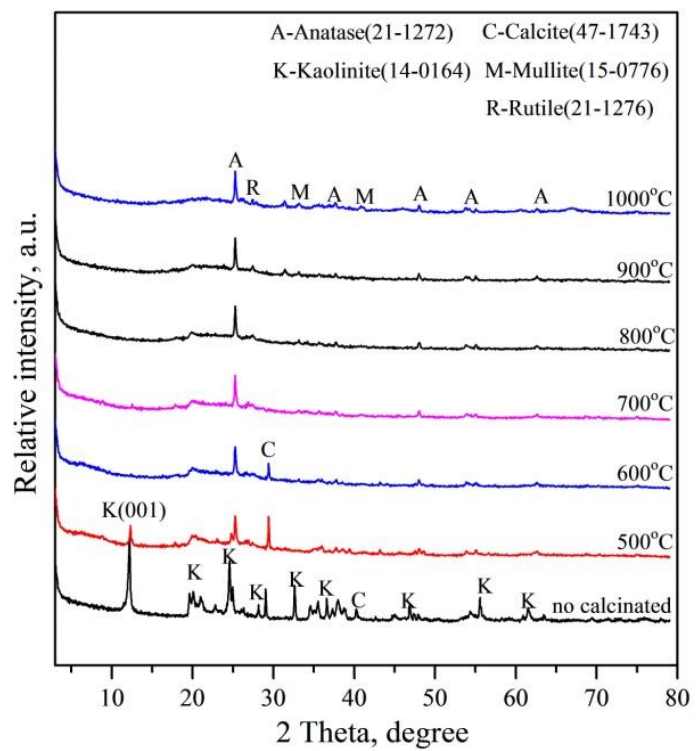

Fig. 3. XRD pattern of waste kaolin calcined at different temperatures

Complementary insights into the structural changes that waste kaolin underwent by thermal treatment were obtained using FTIR spectroscopy (Fig. 4). The spectra for the sample exhibited the following typical bands for kaolinite: $3695,3654,3620 \mathrm{~cm}^{-1}$ (O-H stretching vibrations); 1100 , 794 and $749 \mathrm{~cm}^{-1}$ (Si-O-Si stretching and bending vibrations); 1034, 1008, 697 and $469 \mathrm{~cm}^{-1}$ ( $\mathrm{Si}-\mathrm{O}$ vibrations); $916 \mathrm{~cm}^{-1}$ (Al-OH bending vibrations); and $544 \mathrm{~cm}^{-1}$ (Al(VI)-O-Si bending vibrations) [14-16]. The presence of calcite was confirmed by a shoulder at $\sim 1425 \mathrm{~cm}^{-1}$

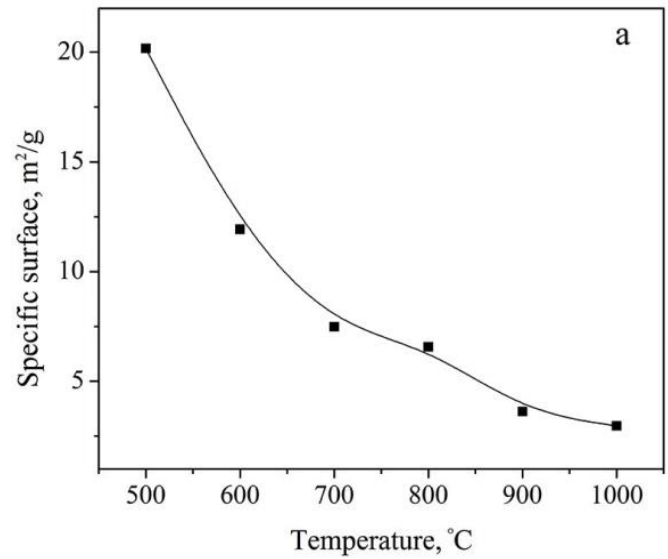

(asymmetric stretching of the carbonate). After the thermal treatment of sample, crystal structure of kaolinite had been destroyed by breaking $\mathrm{O}-\mathrm{H}, \mathrm{Al}-\mathrm{OH}, \mathrm{Al}-\mathrm{O}-\mathrm{Si}$ and $\mathrm{Si}-\mathrm{O}-\mathrm{Si}$ bonds. The disappearance of band at 544 and $916 \mathrm{~cm}^{-1}$ and the appearance of a new band at $800 \mathrm{~cm}^{-1}$ could be connected with the change from octahedral coordination of $\mathrm{Al}^{3+}$ in kaolinite to tetrahedral coordination in metakaolinite. The bands at 1100 and $1200 \mathrm{~cm}^{-1}$ were assigned to amorphous $\mathrm{SiO}_{2}$. The characteristic bands of calcite had totally been disappeared after the thermal treatment over $700{ }^{\circ} \mathrm{C}$. From XRD and FTIR analyses, both techniques confirm the transformation of kaolinite into reactive amorphous phase by heat treatment.

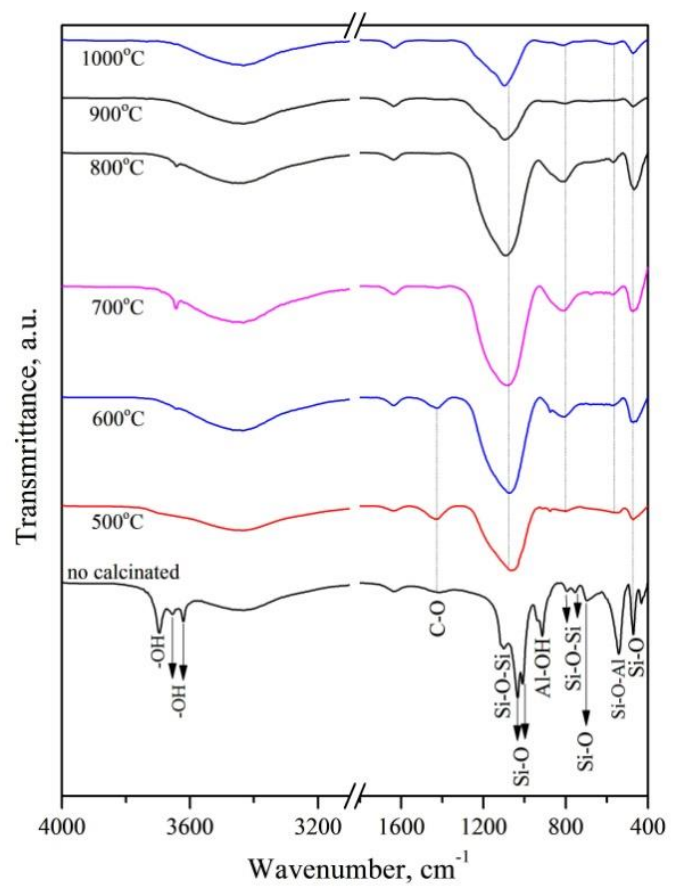

Fig. 4. FTIR spectra of waste kaolin and its calcination products at different temperatures

Previous research suggested that pozzolanic activity was not only determined by chemical composition and structural disorder, but also by specific surface area [5]. Fig. 5 a showed the relationship between the specific surface area of calcined products and the calcination temperature.

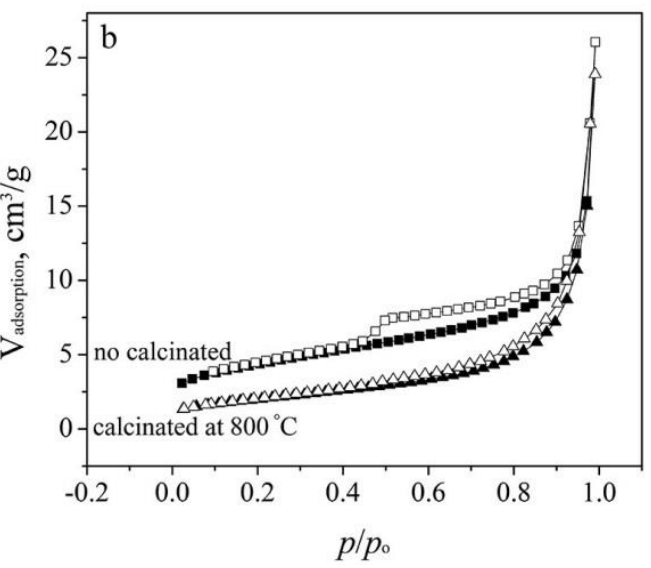

Fig. 5. $a$-specific surface area of calcined products at different temperatures; $b$-nitrogen adsorption and desorption isotherms of waste kaolin and calcinated at $800{ }^{\circ} \mathrm{C}$ 
The gradual decrease of specific surface area was seen from 500 to $1000{ }^{\circ} \mathrm{C}$. The reason was that the agglomeration of the metakaolinite crystals at 500 to $800{ }^{\circ} \mathrm{C}$ and solidphase sintering at 800 to $1000{ }^{\circ} \mathrm{C}[5,17]$. The nitrogen adsorption/desorption isotherm of raw kaolin and calcined products at $800^{\circ} \mathrm{C}$ were shown in Fig. 5 b. It could be seen that raw kaolin showed an IV type $\mathrm{N}_{2}$ adsorption isotherm with an evident hysteresis loop indicating the presence of mesopores in the sample. However, calcined products at $800{ }^{\circ} \mathrm{C}$ had not obvious hysteresis loop because of structural collapse. This phenomenon was consistent with the specific surface area analysis.

\subsection{Pozzolanic activity of calcined products/discussion of the calcination temperature selection}

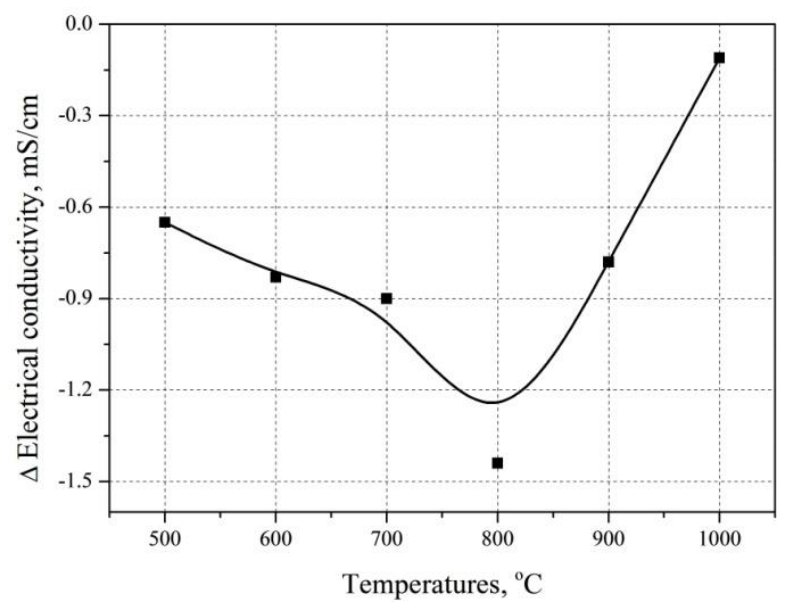

Fig. 6. Loss of electrical conductivity of different solutions at a suspension temperature of $40{ }^{\circ} \mathrm{C}$

The pozzolanic materials can consume calcium ion in aqueous solution by the pozzolanic reaction, resulting in a decrease on electrical conductivity of aqueous solution. So, the electrical conductivity decrease values were often used to evaluate the pozzolanic activity of materials [18]. In order to clarify the variation of electrical conductivity at different calcination temperatures, the electrical conductivity difference value of lime-water solution before and after the addition of calcined products were summarized and shown in Fig. 6. The results showed that the variation of electrical conductivity difference value was significant from $500-1000{ }^{\circ} \mathrm{C}$, which implied the difference reaction activity of calcined products with $\mathrm{Ca}(\mathrm{OH})_{2}$. The electrical conductivity difference value of lime-water solution before and after the addition of calcined products at $500-800{ }^{\circ} \mathrm{C}$ constantly increased, which revealed that increasing of calcination temperature could enhance the activity of the calcined products, which was related to the increase of the content of amorphous active substance. Although calcite decomposition produced calcium oxide that might dissolution in liquid and impact electrical conductivity, the content of calcium oxide was so low that trend of loss of electrical conductivity was not great affected. The maximum electrical conductivity difference value was calcined products at $800{ }^{\circ} \mathrm{C}$, indicating that the best calcination temperature was $800{ }^{\circ} \mathrm{C}$. The electrical conductivity difference value significantly increased from $900{ }^{\circ} \mathrm{C}$ to $1000{ }^{\circ} \mathrm{C}$, which meant that further increase in calcination temperature reduced the pozzolanic activity. According to XRD and FTIR analysis, this decrease might be due to the generation of new phase with low pozzolanic activity. Besides, the variation trend of electrical conductivity difference value was not consistent with the specific surface area, which might be related to the content of active silica and aluminum.

The SAI was the ratio of the compressive strength of blended cement mortar to the strength of the PC mortar at the same age, which was used to indirectly reveal the pozzolanic activity of cement admixture. The results of compressive strength (CS) of PC and Portland blended cements and the SAI were summarized in Table 2. At 3 days and 7 days, it could be observed that the addition of calcined products caused a reduction in the $\mathrm{CS}(\mathrm{SAI}<1.00)$, this reason was that the amount of hydration products formed through the pozzolanic reaction did not yet compensate for the dilution effect. At this stage, the main contribution of calcined products to the hydration process was strongly related to the filler effect, where the degree of reaction of the clinker phases was enhanced due to the extra space available for the hydrates to growth, to the higher water to clinker ratio and to the extra surface provided by the very fine calcined products, that could act as nucleation sites for the hydration products. At 28 days, calcined products mortar presented a SAI greater than 1.0, with the exception of $500{ }^{\circ} \mathrm{C}(\mathrm{SAI}=0.97)$, implying that the contribution of pozzolanic reaction could compensate for the reduction of cementitious materials. It also can be seen that, with the increase of calcination temperature, the SAI of calcined products at each age significantly increased until reaching the maximum at $800^{\circ} \mathrm{C}$. As calcination temperatures further increased to 900 and $1000{ }^{\circ} \mathrm{C}$, the SAI of calcined products slowly decreased because that aluminosilicates recrystallized and the specific surface area decreased. However, the SAI of calcined products 900 and $1000{ }^{\circ} \mathrm{C}$ more than 1, which indicated that even at this high calcination temperature there was still some contribution of the reaction of the calcined material.

Table 2. Compressive strength (CS in MPa) of the PC and blended cement and strength activity index (SAI)

\begin{tabular}{|c|c|c|c|c|c|c|c|c|}
\hline Age, days & & $\mathrm{PC}$ & $500{ }^{\circ} \mathrm{C}$ & $600{ }^{\circ} \mathrm{C}$ & $700{ }^{\circ} \mathrm{C}$ & $800{ }^{\circ} \mathrm{C}$ & $900{ }^{\circ} \mathrm{C}$ & $1000{ }^{\circ} \mathrm{C}$ \\
\hline \multirow{2}{*}{3} & CS & 26.5 & 20.4 & 22.1 & 22.7 & 25.3 & 20.7 & 20.4 \\
\cline { 2 - 11 } & SAI & & 0.77 & 0.83 & 0.86 & 0.95 & 0.78 & 0.77 \\
\hline \multirow{2}{*}{7} & CS & 37.9 & 34.7 & 36.7 & 36.7 & 36.9 & 29.6 & 27.9 \\
\cline { 2 - 11 } & SAI & & 0.92 & 0.97 & 0.97 & 0.97 & 0.78 & 0.74 \\
\hline \multirow{2}{*}{28} & CS & 50.3 & 48.9 & 60.8 & 62 & 63.1 & 61.7 & 52.4 \\
\cline { 2 - 10 } & SAI & & 0.97 & 1.21 & 1.23 & 1.25 & 1.23 & 1.04 \\
\hline
\end{tabular}


The blended cements with calcined products at $800{ }^{\circ} \mathrm{C}$ had the highest compressive strength at all test ages, demonstrating that $800{ }^{\circ} \mathrm{C}$ was the best calcination temperature.

\subsection{Effect of calcined products on hydration of PC and formation of hydration products}

In order to further evaluation the effect of calcined products at $800{ }^{\circ} \mathrm{C}$ on the hydration of blended systems, phase composition and microstructure of the hydration products of pure cement paste and calcined products blended cement paste at different ages were analyzed and results were shown in Fig. 7 and Fig. 8. The results shown that the main hydration products of blended systems was calcium hydroxide $(\mathrm{CH})$, ettringite $(\mathrm{Ett})$ and calcium silicate hydrate $(\mathrm{CSH})$ at 3 day and 28 day, which suggested that calcined products did not change the types of hydration products $[19,20]$. At 3 days (Fig. 7 a), the peak intensity of $\mathrm{CH}$ decreases as the content of calcined products increases due to the dilution effect rather than the pozzolanic reaction according to previous research. At 28 days (Fig. 7 b), the peak intensity of $\mathrm{CH}$ from blended cement paste was lower than pure cement paste and blended cement paste at 3 days, which might because $\mathrm{CH}$ was consumed by pozzolanic reaction with calcined products [7, 21-23]. The pozzolanic reaction between $\mathrm{CH}$ and calcined products formed calcium silicate hydrate, decreased the pores of crystalline hydration products, made the microstructure denser and improved the impermeability and durability. Besides, the diffraction peak of anatase as the impurity minerals was observed, which suggested that anatase did not participate in the hydration reaction and might play a role of fill effect in the paste.

The SEM images of pure cement paste and calcined products blended cement paste at 3 and 28 days were shown in Fig. 8. At 3 days, it could be seen that ettringite needles in calcined products blended cement paste was more than pure cement paste, which might be because that calcined products delayed hydration of the cement. In this period, the degree of reaction of calcined products in blended cement paste was low [24]. The calcination products mainly played the role of the dilution effect and fill effect in pastes. At 28 days, the microstructure of cement pastes had become denser and stronger. The ettringite needles were no longer seen, probably being converted to monosulfate resulting in the densification of the microstructure. Comparting the microstructure of cement paste with and without calcined products at 28 day, it is found that although the basic hydration products displayed no great differences, there was more crystalline $\mathrm{CH}$ in pure cement paste. Similar results were reported by Zhang [25].
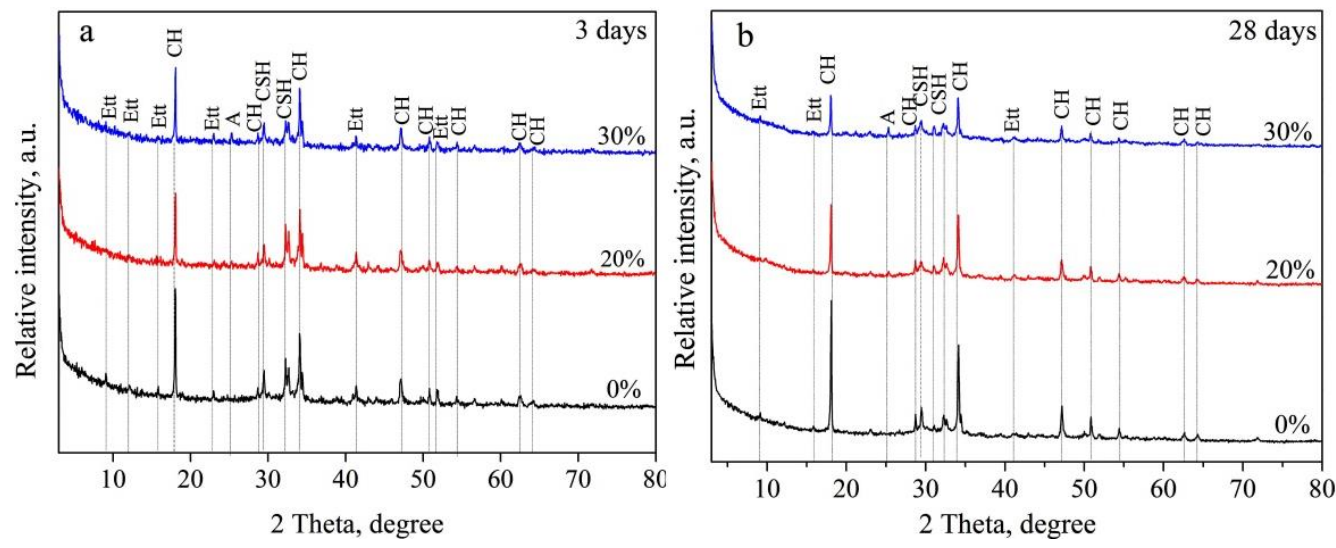

Fig. 7. XRD patterns for different hydrated pastes at: $\mathrm{a}-3$ days; $\mathrm{b}-28$ days. $\mathrm{CH}$ - calcium hydroxide; Ett - ettringite; $\mathrm{CSH}-\mathrm{calcium}$ silicate hydrates; A - anatase

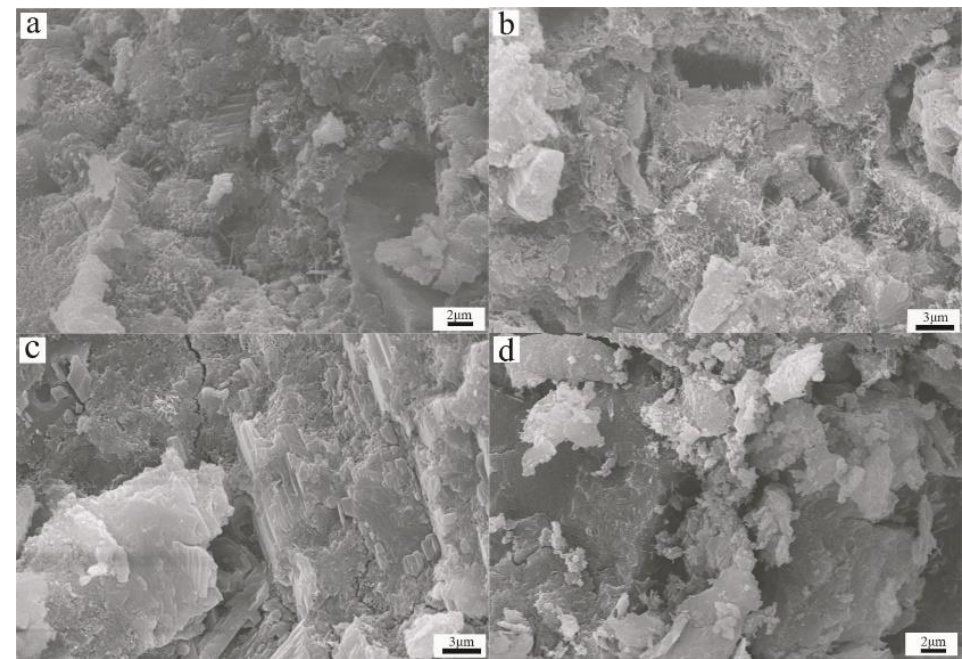

Fig. 8. SEM images of cement paste: $a$-pure cement paste at 3 days; $b$-calcined products paste at 3 days; $c$-pure cement paste at 28 days; $\mathrm{d}-$ calcined products paste at 28 days 
This observation also showed that the $\mathrm{CH}$ was consumed by pozzolanic reaction with calcined products in blended cement paste, and it was in good agreement with the XRD analysis of hydrated pastes.

\section{CONCLUSIONS}

The investigation on waste kaolin from southwest of China used for the preparation of pozzolanic material by calcination at $500-1000{ }^{\circ} \mathrm{C}$, showed that the calcined products mainly was metakaolinite and had high pozzolanic activity. The de-hydroxylation behavior of waste kaolin occurred at $450-630^{\circ} \mathrm{C}$. The transformation of the anatase crystal structure and recrystallization of the metakaolinite occurred around $900{ }^{\circ} \mathrm{C}$. The results of electrical conductivity test and strength activity index test of calcined products were consistent, which showed that the optimal calcinations temperatures for conversion into metakaolin with a high pozzolanic index were $800^{\circ} \mathrm{C}$. The solid-phase sintering at higher temperature decreased the pozzolanic activity. XRD and SEM analysis of the hydration of blended systems could conclude that the calcined products had high pozzolanic activity and could consumed calcium hydroxide by pozzolanic reaction. Therefore, waste kaolin from southwest of China could be used as pozzolanic material by calcination, which would minimize environmental problems and consume waste resources.

\section{Acknowledgements}

This work was financially supported by the National Natural Science Foundation of China (50804039), Geological Surve Foundation of Ministry of Land and Resources of China (Grant No. ZHS-QRK-15-043), Science and Technology Support Program of Sichuan Province of China (Grant No. 2016GZ0308) and the Platform Fund of Southwest University of Science and Technology (Grant No. 14tdgk04).

\section{REFERENCES}

1. Liu, X., Fan, Y., Wang, C. An Estimation of the Effect of Carbon Pricing for $\mathrm{CO}_{2}$ Mitigation in China's Cement Industry Applied Energy 185 2017: pp. 671-686.

2. Rashad, A.M., Zeedan, S.R. The Effect of Activator Concentration on the Residual Strength of Alkali-Activated Fly Ash Pastes Subjected to Thermal Load Construction and Building Materials 25 2011: pp. 3098-3107. https://doi.org/10.1016/j.conbuildmat.2010.12.044

3. Tsakiridis, P.E., $\quad$ Papadimitriou, G.D., $\quad$ Tsivilis, S., Koroneos, C. Utilization of Steel slag for Portland Cement Clinker Production Journal of Hazardous Materials 152 2008: pp. $805-811$. https://doi.org/10.1016/j.jhazmat.2007.07.093

4. Juenger, M.C.G., Winnefeld, F., Provis, J.L., Ideker, J.H. Advances in Alternative Cementitious Binders Cement and Concrete Research 41 2011: pp. 1232-1243. https://doi.org/10.1016/j.cemconres.2010.11.012

5. Alujas, A., Fernández, R., Quintana, R., Scrivener, K.L., Martirena, F. Pozzolanic Reactivity of Low Grade Kaolinitic Clays: Influence of Calcination Temperature and Impact of Calcination Products on OPC Hydration Applied Clay Science 108 2015: pp. 94-101. https://doi.org/10.1016/j.clay.2015.01.028

6. Taylor-Lange, S.C., Lamon, E.L., Riding, K.A., Juenger, M.C.G. Calcined kaolinite-Bentonite Clay Blends as Supplementary Cementitious Materials Applied Clay Science 108 2015: pp. 84-93.

https://doi.org/10.1016/j.clay.2015.01.025

7. Tironi, A., Trezza, M.A., Scian, A.N., Irassar, E.F. Potential Use of Argentine Kaolinitic Clays as Pozzolanic Material Applied Clay Science 101 2014: pp. 468-476. https://doi.org/10.1016/j.clay.2014.09.009

8. Luxan, M.P., Madruga, F., Saavedra, J. Rapid Evaluation of Pozzolanic Activity of Natural Products by Conductivity Measurement Cement and Concrete Research 19 1989: pp. 63-68. https://doi.org/10.1016/0008-8846(89)90066-5

9. Yu, Q., Sawayama, K., Sugita, S., Shoya, M., Isojima, Y. The Rreaction between Rice Husk Ash and $\mathrm{Ca}(\mathrm{OH}) 2$ Solution and the Nature of its Product Cement and Concrete Research 29 1999: pp. 37-43. https://doi.org/10.1016/S0008-8846(98)00172-0

10. Liu, Y.Y., Lei, S.M., Lin, M., Li, Y., Ye, Z., Fan, Y.M. Assessment of Pozzolanic Activity of Calcined Coal-series Kaolin Applied Clay Science 143 2017: pp. 159-167. https://doi.org/10.1016/j.clay.2017.03.038

11. Mockovciakova, A., Iveta, S., Jiri, S., Ivana, K. Characterization of Changes of Low and High Defect Kaolinite after Bioleaching Applied Clay Science 39 2008: pp. 202-207. https://doi.org/10.1016/j.clay.2007.06.002

12. Guo, M.R., Lin, Y.M., Xu, X.P., Chen, Z.L. Bioleaching of Iron from Kaolin using Fe(III)-reducing Bacteria with Various Carbon Nitrogen Sources Applied Clay Science 48 2010: pp. $379-383$. https://doi.org/10.1016/j.clay.2010.01.010

13. Sanchez, R.M.T., Basaldella, E.I., Marco, J.F. The Effect of Thermal and Mechanical Treatments on Kaolinite: Characterization by XPS and IEP Measurements Journal of Colloid and Interface Science 215 1999: pp. 339-344. https://doi.org/10.1006/jcis.1999.6241

14. Madejová, J. FTIR Techniques in Clay Mineral Studies Vibrational Spectroscopy 31 2003: pp. 1-10. https://doi.org/10.1016/S0924-2031(02)00065-6

15. Repacholi, M. Clay Mineralogy: Spectroscopic and Chemical Determinative Methods; Springer Science \& Business Media, 2012.

16. Saikia, N., Bharali, D., Sengupta, P., Bordoloi, D., Goswamee, R., Saikia, P., Borthakur, P. Characterization, Beneficiation and Utilization of a Kaolinite Clay from Assam, India Applied Clay Science 24 2003: pp. 93-103. https://doi.org/10.1016/S0169-1317(03)00151-0

17. Lee, V.G., Yeh, T.H. Sintering Effects on the Development of Mechanical Properties of Fired Clay Ceramics Materials Science and Engineering: A 485 2008: pp. 5-13. https://doi.org/10.1016/j.msea.2007.07.068

18. Tironi, A., Trezza, M.A., Scian, A.N., Irassar, E.F. Assessment of Pozzolanic Activity of Different Calcined Clays Cement \& Concrete Composites 37 2013: pp. 319-327. https://doi.org/10.1016/j.cemconcomp.2013.01.002

19. Mostafa, N.Y, Brown, P.W. Heat of Hydration of High Reactive Pozzolans in Blended Cements: Isothermal Conduction Calorimetry Thermochimica Acta 435 2005: pp. $162-167$.

https://doi.org/10.1016/j.tca.2005.05.014 
20. Tironi, A., Castellano, C.C., Bonavetti, V.L., Trezzaa, M.A., Scian, A.N., Irassara, E.F. Kaolinitic Calcined Clays-Portland Cement System: Hydration and Properties Construction \& Building Materials 64 2014: pp. 215-221.

https://doi.org/10.1016/j.conbuildmat.2014.04.065

21. Gasparini, E., Tarantino, S.C., Ghigna, $\mathbf{P}$. Riccardi, M.P., Cedillo-González, E.I., Siligardi, C., Zema, M. Thermal Dehydroxylation of Kaolinite under Isothermal Conditions Applied Clay Science 80-81 2013: pp. $417-425$. https://doi.org/10.1016/j.clay.2013.07.017

22. Said-Mansour, M., Kadri, E.H., Kenai, S., Ghrici, M., Bennaceur, R. Influence of Calcined Kaolin on Mortar Properties Construction and Building Materials 25 2011: pp. $2275-2282$. https://doi.org/10.1016/j.conbuildmat.2010.11.017

23. Souri, A., Golestani-Fard, F., Naghizadeh, R., Veiseh, S. An Investigation on Pozzolanic Activity of Iranian Kaolins Obtained by Thermal Treatment Applied Clay Science 103 2015: pp. 34-39. https://doi.org/10.1016/j.clay.2014.11.001

24. Poon, C.S., Lam L., Kou, S.C., Wong, Y.L., Wong R. Rate of Pozzolanic Reaction of Metakaolin in HighPerformance Cement Pastes Cement and Concrete Research 31 2001: pp. 1301-1306. https://doi.org/10.1016/S0008-8846(01)00581-6

25. Zhang, M.H. Microstructure, Crack Propagation, and Mechanical Properties of Cement Pastes Containing High Volumes of Fly Ashes Cement and Concrete Research 25 1995: pp. $1165-1178$. https://doi.org/10.1016/0008-8846(95)00109-P 